\title{
Some Observations About the Strict Liability of the Maker of Prescription Drugs: The Aftermath of MER/29
}

\section{Page Keeton*}

$\mathbf{R}^{\mathrm{n}}$ EFERENCE HAS OFTEN BEEN MADE to the current scientific and technological revolution which involves a proliferation of chemicals, especially drugs and cosmetics. ${ }^{1}$ We are justified in referring to this age as one both of chemotherapy-the treatment of disease with chemical agentsand of chemocosmetology-the improvement of appearance through treatment of the skin and hair. ${ }^{2}$ Although most people would admit that this proliferation of new drugs and cosmetics has on the whole benefited humanity, these benefits to the many are coming at high cost to the few. Miscarriages can and do often occur in the manufacturing, distributing, and using processes, with more and more persons being injured as a result. This increase in harm is accompanied, however, by an enhanced concern for the injured, provoking a reexamination of those principles, both contractual and tortious, which govern the shifting of losses from those injured to those directing the manufacturing, distributing, and using processes.

One consequence of these changes has been a vast increase in litigation; a single product can often result in claims involving millions of dollars. A recent example is $M E R / 29$, which was made and sold as an anticholesterol drug. ${ }^{3}$ While it was hoped that MER/29 would have a significant effect on the rate of heart disease, it caused serious side effects including cataracts in the eyes of some users and was ultinately withdrawn from the market. Over a thousand personal injury suits were filed in its aftermath. ${ }^{4}$

The observations in this Article flow directly from the appellate opinions in some of those MER/29 cases. ${ }^{5}$ The variety of judicial results

\footnotetext{
* Dean, School of Law, University of Texas, Austin.

I National Observer, May 3, 1965; Address by Edward D. Downing, Peculiar Problems in Pharmaceutical Cases, at Legal Institute, University of Arkansas, Oct. 1965.

2 Keeton, Products Liability-Some Observations About Allocation of Risks, $64 \mathrm{MrcH}$. L. REv. 1329 (1966).

${ }^{3}$ See Rheingold, The MER/29 Story-An Instance of Successful Mass Disaster Litigation, 56 CALTF. L. REv. 116 (1968).

${ }^{4} I d$. at 118.

${ }^{5}$ See Roginsky v. Richardson-Merrell, Inc., 378 F.2d 832 (2d Cir. 1967); Blun v. Richardson-Merrell, Inc., 268 F. Supp. 906 (D. Md. 1965); Bennett v. Richardson-Merrell, Inc., 231 F. Supp. 150 (ED. Ill. 1964); Toole v. Richardson-Merrell, Inc., 251 A.C.A. 785, 60 Cal. Rptr. 398 (1967); McLeod v. W.S. Merrell Co., 174 So. 2d 736 (Fla. 1965); Lewis
} 
reached in suits involving the same product demonstrates the legal complexities and the uncertainties involved in resolving such claims. Furthermore, cases based on one factual situation which produce such inconsistent results both as to the facts and the law undermine one's confidence in the judicial process.

BASES OF THE MLANUFACTURER'S IIABILITY

Results in the MER/29 cases were varied, although not all mutually inconsistent. One result was no habihity at all under any theory. ${ }^{\circ}$ Other results suggest various bases of hability, including hability based on the maker's negligence in producing and selling such a product, however free from defects, ${ }^{7}$ and liability based on the maker's negligence in failing adequately to warn either physicians or users of possible dangers. ${ }^{8}$ Liability in some cases was also based on recklessness, resulting in large jury awards for punitive damages without regard either to punitive damages assessed in other MER/29 cases or to the effect on settlements of allowing punitive damages. ${ }^{9}$ The granting of punitive damages itself raises serious questions, constitutional and otherwise, about punishing individuals and corporations in this manner. Other theories included hability arguably based upon the maker's fraud and dishonesty in failing to disclose or misrepresenting to the Food and Drug Administration (FDA) the facts related to the testing procedures utilized; ${ }^{10}$ and liability without respect to fault, based either on theories of tort or of warranty, accompanied by a variety of ideas about the scope of the warranty or the ambit of responsibility in tort.11

Such results illustrate the fact that the substantive rules of legal liability must take account of the practical limits to effective legal action. Distinctions which are theoretically sound in principle may become unworkable in practice because of the time required and the difficulties involved in ascertaining the findings of fact that sucl distinctions require. No effort will be made here, however, to do anything more than to make some

v. Baker, 243 Ore. 317, 413 P.2d 400 (1966); Cudmore v. Richardson-Merrell, Inc., 398 S.W.2d 640 (Tex. Civ. App. 1965).

6 Blum v. Richardson-Merrell, Inc., 268 F. Supp. 906 (D. Md. 1965); McLcod v. W.S. Merrell Co., 174 So. 2d 736 (Fla. 1965); Lewis v. Baker, 243 Ore. 317, 413 P.2d 400 (1966); Cudmore v. Richardson-Merrell, Inc., 398 S.W.2d 640 (Tex. Civ. App. 1965).

7 See Roginsky v. Richardson-Merrell, Inc., 378 F.2d 832 (2d Cir. 1967); Toole v. Richardson-Merrell, Inc., 251 A.C.A. 785, 60 Cal. Rptr. 398 (1967).

8 See cases cited noted 7 supra.

9 See cases cited note 7 supra.

10 See cases cited noted 7 supra.

11 See Toole v. Richardson-Merrell, Inc., 251 A.C.A. 785, 60 Cal. Rptr. 398 (1967). 
suggestions regarding how the law of loss distribution should be developed in this general area.

First, one general suggestion is that the system of strict liability currently evolving in the courts should perhaps altogether replace hability based on theories of negligence. It may no longer be tolerable in trying cases to a jury to maintain two theories of recovery with different defenses and different rules. A claimant, on proof of recklessness, should still be able to recover punitive damages, however, and still should enjoy an independent ground of recovery on a theory of the manufacturer's misrepresentation or nondisclosure in inducing the FDA to give its approval. ${ }^{12}$ In fact, reliance by the FDA on false and fraudulent representations should itself provide a cause of action for those who can show that the product resulted in their injury. The rules restricting responsibility for economic losses suffered as a result of fraudulent or negligent misrepresentations should not necessarily limit recovery for physical harm.

\section{A. The Scope of Strict Liability}

Because it is obvious that a manufacturer should not be hable for damages simply for putting into circulation a product which injures someone, it has generally been assumed that strict hability inust rest on a finding that the product was defective or unsuitable. The term "unsuitable" has generally been used by courts basing liability on a warranty theory, whereas the term "defective" customarily refers to strict hability in tort. In a recent and thoughtful article, Dickerson has suggested that the basic question is: "How good does a product have to be to satisfy the legal responsibilities of its maker and its distributors?"13 However, if the burden of proof is on the claimant, as it has always been, the issue may rather be: "How harmful does a product have to be in order to breach the obligation of the maker and its distributors?" The question then is how bad, not how good, a product must be.

12 See both the district court opinion and the circuit court opinion in Roginsky v. Richardson-Merrell, Inc., 254 F. Supp. 430 (D.N.Y. 1966), and 378 F.2d 832 (2d Cir. 1967). As Judge Friendly indicated in the Second Circuit opinion, one's liability for fraud generally has been said to extend only to the persons or class of persons whom he intends or has reason to expect to act, or to refrain from action, in reliance upon the misrepresentation and who in fact do rcly. 378 F.2d 832, 837 (2d Cir. 1967). When information is required by statute, hability extends to all persons who have justifiably relied thereon. ResTATEMENT (SECOND) OF TORTS $\S \S 531,536$ (Tent. Draft No. 10, 1964). There are several complications here, and Judge Friendly merely said: "Given our limited capacity as predictors of New York law, we would prefer to avoid decision of such a weighty and difficult issue, with wide ramifications as to other products, if we permissibly can." $378 \mathrm{~F} .2 \mathrm{~d}$ at 837.

13 Dickerson, Products Liability: How Good Does A Product Have To Be? 42 IND. L.J. 301 (1967). 
The MER/29 cases suggest a variety of answers to this question, estabhshing different tests by which to judge the manufacturer's liability. In the California case of Toole v. Richardson-Merrell, Incorporated, ${ }^{14}$ the trial judge instructed the jury to allow a user to recover on the basis of implied warranty if it found "that he purchased MER/29 as recommended by his physician; that the drug was capable of causing harmful side effects when taken as recommended, and that plaintiff's injuries were, with reasonable probability, caused by the use of the drug."15 According to this instruction, if a victim uses a drug pursuant to a physician's prescription and if there is proof that the drug has caused side effects on some occasions, then a jury could find it "capable" of causing harmful side effects, and, absent evidence of other causes, could find the drug to have caused the plaintiff's injury. ${ }^{16}$ It would seem that such an instruction is clearly erroneous unless the scope of strict liability is to extend to anyone harmed by a prescription drug used according to his plyysician's directions.

\section{B. The Effect of FDA Approval}

The defendant manufacturer in Toole contended that no warranty is applicable to the sale of unadulterated and uncontaminated prescription drugs. In another MER/29 case, Lewis v. Baker, the Oregon Supreme Court seems to have adopted this contention. ${ }^{17}$ The jury found at the trial that the drug was properly tested, appropriately labeled, approved by the FDA, and marketed properly under federal regulations. The court held that under such findings $\mathrm{MER} / 29$ must be regarded as a safe product as a matter of law. Accordingly, a person claiming injury inust prove an impurity to recover. This would himit strict liability regarding drugs approved by the FDA - and marketed with appropriate labels, advice as to dangers,

14251 A.C.A. 785, 60 Cal. Rptr. 398 (1967).

15 Id. at 804, 60 Cal. Rptr. at 412.

16 Because the jury awarded a large recovery for punitive damages, which was necessarily based on a finding of either fraud or recklessness, any error in the instruction was no doubt harmless. Id. at 811, $60 \mathrm{Cal}$. Rptr. at 416. The court said: "In our case there is evidence from which the jury could conclude that appellant brought its drug to market, and maintained it on the market, in reckless disregard of the possibility that it would visit serious injury upon persons using it." Id. at 810,60 Cal. Rptr. at 416. In Roginsky v. Richardson-Merrell, Inc., 378 F.2d 832, 850-51 (2d Cir. 1967), the court of appeals set aside the judgment for punitive danages and Judge Friendly said:

Moreover, New York demands, as it might have to before punishing a defendant with fines similar to those imposed on a criminal charge, that the quality of the conduct necessary to justify punitive damages inust be "clearly established." [citations omitted] ... It would be hard to think of a situation more appropriate for invoking that standard than where the manufacturer of a new drug honestly beheved to assist in prolonging human life is faced with claims for penalties by hundreds of plaintiffs rumning into millions of dollars, in addition to many millions more for damages sustained.

17 Lewis v. Baker, 243 Ore. 317, 413 P.2d 400 (1966). 
and directions for use-to a situation in which the plaintiff could prove a dangerous condition resulting from a miscarriage in the manufacturing process, such as the live virus in polio vaccine. ${ }^{18}$

The scope of liability establislied in Lewis is clearly narrower than that of the Toole jury instruction. First, the Lewis test would mean that there would be no liability for side effects, foreseeable or unforeseeable, knowable or unknowable, if the product liad been approved by the FDA. The court apparently reasoned that the FDA's decision should be conclusive on the issue whether benefits to the many from use of the drug outweighed harmful side effects to the few. Second, the test would mean that lowever bad a product turned out to be after a period of use, and even though it was withdrawn from the market, those who were injured could not recover. The Lewis standard would have the advantages both of simplifying the litigation process and of producing more uniform results in like situations. It would eliminate the almost impossible task of trying to decide what is and what is not scientifically knowable at a given time, a distinction suggested in the Second Restatement. ${ }^{19}$ It would also eliminate arguments about the adequacy of warnings and instructions. Courts trying these cases today have the burden of examining voluminous evidence regarding the incidence of harm during periods of marketing; the facts which scientists could, by the best methods available to them, have discovered; and the adequacy of the warnings and directions.

Despite the advantages of accepting FDA approval as conclusive, it can reasonably be argued that this view is inconsistent with the generally accepted notion that legislative safety standards are only minimum requirements and are not conclusive on the issue of due care..$^{20}$ It must be recognized, however, that the process involved in approving a drug is quite different from that involved in adopting a legislative safety standard. In the former situation, the question is whether approval of a particular product should be final or whether every jury slould be allowed to decide the question independently. In cases $m$ which an actor's conduct has been held to be negligent under the particular circumstances despite his compliance with a general legislative standard of conduct, the legisla-

18 Gottsdanker v. Cutter Laboratories, Inc., 182 Cal. App. 2d 602, 6 Cal. Rptr. 320 (1960). Most of the leading cases applying principles of warranty or strict liability since the landmark case of Henningsen v. Bloomfield Motors, Inc., 32 N.J. 358, 161 A.2d 69 (1960), have involved harm resulting from an unintended condition, i.e., a miscarriage in the manufacturing process. Examples of these conditions are the defective steering wheel of the automobile in Henningsen; the defective altimeter of the airplane in Goldberg v. Kollsman Instrument Corp., 12 N.Y.2d 432, 191 N.E.2d 81 (1963); and the defective fork stem of the wheelchair in Putman v. Erie City Mfg. Co., 338 F.2d 911 (5th Cir. 1964).

10 Restatement (Second) of TORTs $\$ 402 \mathrm{~A}$, comment $k$ (1965).

20 W. Prosser, HandBook of the Law of Torts $\$ 35$, at 205 (3d ed. 1964); cf. Nader \& Page, Automobile Design and the Judicial Process, 55 CaIrF. L. Rev. 645, 674 (1967). 
ture or administrative agency which set the standard has not approved the particular conduct in question.

If FDA approval is accepted as conclusive, the position of the Oregon Supreme Court unduly limits liability unless the subsequent withdrawal of a product permits imposition of hability on the maker. If there is to be no evaluation of the FDA's actions in approving the drug, the risk of subsequent withdrawal should be borne by the maker. Moreover, if FDA approval is to be conclusive, those who are victimized by drugs sliould, within a reasonable time thereafter, be able to institute proceedings for withdrawal of the drugs. Strict liability for subsequently withdrawn drugs miglit well discourage the development and marketing of new drugs. On the other hand, it would tend to induce great care prior to marketing on the part of makers of new drugs without burdening the courts with timeconsuming inquiries as to whether precautions required by the FDA and other reasonable precautions were taken prior to marketing. Unless liability is imposed for withdrawn drugs, protection for the public will be inadequate. In the light of the development of so many new drugs, it is unrealistic to rely on a busy administrative agency to assure that proper precautions have been taken.

II

LIABILITY TO THE ALLERGIC USER

The MER/29 cases raise questions concerning not only the general scope of hability for the drug manufacturer, but also specific problem areas. A Texas case involving MER/29, Cudmore v. Richardson-Merrell, Incorporated, ${ }^{21}$ raised the question of liability to allergic drug users. The case stated that the maker of a drug intended for liuman consumption or intimate bodily use should be held hable on the grounds of implied warranty for injurious results only when a person of ordinary care ought reasonably to have foreseen sucl results to an appreciable number of persons. It was found at the trial that the plaintiff's injury was not foreseeable because when the plaintiff suffered his injury it was scientifically unknowable that the drug did cause cataracts to an appreciable class of persons. Thus, a drug maker would be liable to allergic victims who use a prescription drug pursuant to a physician's directions when the drug is known to cause allergic reactions or side effects to an appreciable number of persons. The opimion also indicates that however bad the product turns out to be, there is no liability to those injured prior to discovery of the truth. As would appear from what has already been said, I submit that both propositions are highly questionable. The former, like the Toole jury instruc-

21398 S.W.2d 640 (Tex. Civ. App. 1965). 
tion, extends the scope of liability too broadly, and the latter, like the Lewis case, fails to provide adequate protection for the injured.

The problem of liability for allergic reactions is a difficult one. In cases involving cosmetics, several courts liave permitted injured users to recover when the jury finds from the evidence that there was an ingredient in the product to which an appreciable class of persons were allergic and that the plaintiff was in that class. ${ }^{22}$ However, there lias been no such line of authorities supporting the imposition of liability on the maker of drugsproducts for the treatment of disease-as distinguished from cosmeticsproducts for the improvement of the appearance.

Neither the warranty provisions of the Uniform Commercial Code, ${ }_{2}^{23}$ nor the applicable section of the Second Restatement, ${ }^{24}$ would make provision for recovery to the allergic user of either a drug or a cosmetic unless the side effects were such as to make the product "unfit" or "unreasonably dangerous," those being the respective terms employed to describe a bad product. Under the Uniform Commercial Code a product is unmerchantable if unfit "for the ordinary purposes for which such goods are used." Does this mean unfit to the particular user for ordinary purposes or to the normal user? Perhaps it does not mean either; the drafters were probably not thinking of the allergic user. Dickerson suggests that "[a]t least, we can be sure that to constitute a legal defect the offending condition must be one that the typical consumer of the product does not anticipate and guard against. The product must betray his reasonable, established expectations."26 These statements, however, do not answer the question at issue. The typical consumer or user may be aware of the dangers of allergic reactions and yet not anticipate or guard against them. Although the product is no different than anticipated, the consumer does not expect to be in the group of those who are sensitive to it. The issue is broader than the nature of the product. The problem is better stated by the Supreme Court of Oregon when it inquires whether social justice requires that "the price

22 Crotty v. Shartenberg's-New Haven, Inc., 147 Conn. 460, 162 A.2d 513 (1960) (hair remover); Reynolds v. Sun Ray Drug Co., 135 N.J.L. 475, 52 A.2d 666 (Ct. Err. \& App. 1947) (lipstick); Esborg v. Bailey Drug Co., 61 Wash. 2d 347, 378 P.2d 298 (1963) (hair tint). Contra, Jacquot v. Filene's Sons Co., 337 Mass. 312, 149 N.E.2d 635 (1958); Bennett v. Pilot Prods. Co., 120 Utah 474, 235 P.2d 525 (1951). In Gober v. Revlon, Inc., 317 F.2d 47 (4th Cir. 1963), the maker of a base coat for nail polish was held liable to the plaintiff for injuries caused by an allergic reaction. Although the court concluded that the evidence justified a finding of negligence for failure to warn about this risk, it observed that under California law, which governed the case, the plaintiff could have recovered without negligence and simply because her imjuries resulted from an allergic reaction or from her own peculiar sensitivity.

23 UnIforar Commrerctal Code § 2-314.

24 Restatentent (Second) of ToRts $\S 402 A$ (1965).

25 UnIForar Coanmerctat Code § 2-314.

26 Dickerson, supra note 13 , at 306 . 
of the drugs should include an amount sufficient to create a fund to compensate those who suffer unanticipated harm from the use of a beneficial drug."27

Since the principal reason now widely accepted for shifting losses from consumers to makers is not fulfilling consumer expectations but the makers' capacity to distribute the losses of the few among all purchasers, ${ }^{28}$ the fact that the product is basically what the consumer expects it to be does not itself determine whether a particular identifiable risk should be allocated to the maker rather than the user-victim. For example, the fact that the user is aware of the automobile maker's failure to comply with statutory standards or reasonable care in guarding against either the first or the "second collision"29 does not necessarily mean that the risk of harm for disregarding such standards should fall on the knowing victim. On the other hand, the victim's knowledge is relevant, because the cost of his injuries will be passed on to the public in a higher price for the product. The basic assumption, sometimes made, that it is best to allocate a particular identifiable risk of harm inherent in the use of a product to the maker simply because he can shift the losses from such hazard to the consuming public in the form of higher prices is an economic assumption of dubious validity, especially in the light of other methods available to members of the general public for securing themselves against tragic events.

Neither the Second Restatement nor the Uniform Commercial Code would allow recovery by the allergic user, and economic loss-spreading arguments do not necessarily support such recovery. A number of other factors argue against recovery by the so-called allergic victim. Recovery only for true allergies involves making a distinction between an idiosyncratic sensitivity, an allergic reaction, and perhaps even just a predisposition of some kind to an injury. Lung cancer from cigarettes, for example, is perhaps not, medically speaking, an allergic reaction, and alcoholism is perhaps not the result of an allergy. Although distinguishing between allergic and idiosyncratic reactions for purposes of "risk spreading" is theoreti-

27 Cochran v. Brooke, 243 Ore. 89, 95-96, 409 P.2d 904, 907 (1966).

28 Keeton, Products Liability-Some Observations About Allocation of Risks, 64 Mrcrr. L. REv. 1329,1333 (1966). One or more, or all of three reasons are usually given in justification for the imposition of some form of strict hability on makers of products-the prevention of the frustration of consumer expectations, the reduction of the incidence of harm, and the capacity of makers to shift losses of the few to the many who purchase the maker's product.

29 See R. NADER, Unsafe At ANy SPEed 81 (1965). The spotlight of pubicity on the automobile's unsafe design features has resulted in the passage of safety legislation by Congress. Because of the nature of the problem, it is to governmental regulation, and particularly to federal reguiation, that we must turn if any significant impact is to be made on the incidence of injuries from accidents generally, and from traffic accidents in particular. See Nader \& Page, supra note 20, at 669-73. 
cally sound, ${ }^{30}$ basing liability on such a distinction involves complicated factual findings similar to those required by independent judicial examination of the factual data underlying FDA approval. Unless recovery is to be allowed in every case in whicl injury results from a product used appropriately, the practical difficulties of making the necessary distinctions should probably prevent allergic victims from recovering.

The question of recovery for allergy suggests a similar but broader issue. When an admittedly good drug results in injury, there is always the likelihood that the drug was misused, overused, or that directions were not followed. There is often no way to contradict the user's evidence as to how the product was used. In identifying various causes for unintended consequences resulting from the use of products, and in seeking solutions to the problems of allocating various risks, one's attention must be directed to the user as well as the inaker.

Focus on the user suggests that the adequacy of the inaker's warnings should be important in determining the scope of liability. In a case involving a drug for treating arthritis, for example, the plaintiff recovered damages for a permanent eighty per cent loss of vision. ${ }^{31}$ Liability rested on the inanufacturer's negligence in failing to give adequate warning. The doctor was provided with literature warning of side effects, and the maker did comply with all FDA regulations. The court held that the duty to exercise reasonable care in giving warning and instructions as to use was not necessarily satisfied by compliance with FDA regulations, whicll were only minimal requirements. The jury was therefore justified in finding that the failure of the maker's representative to warn the doctor personally was negligence. Earher in this Article it was suggested that FDA approval of a drug might well be considered conclusive unless the drug was later withdrawn either by the FDA or by the company voluntarily. FDA regulations as to notice would seem to be in a different category. Because those regulations are general standards applicable alike to all situations,

\footnotetext{
30 See Dickerson, supra note 13, at 328-29:
}

There has been much general talk about "risk spreading," but risk spreading assumes a definable risk, a minimum degree of "typicality" that provides the necessary actuarial basis for insurance. A definable risk, in turn, assumes a class of victim definable by the time of trial at the latest.

This explains, I think, the significant legal difference between the person who is allergic and the person who is merely idiosyncratic. The allergy cases are often misunderstood because, although most of them can be read as denying relief to persons who are allergic, many plaintiffs lave failed because they failed to show that they were members of identifiable classes; that is, that they were other than idiosyncratics.

31 Yarrow v. Sterling Drug, Inc., 263 F. Supp. 159 (D.S.D. 1967). The case involved chloroquine phosphate, sold under the tradename "Aralen." In another case involving the same drug, there was a finding of fact in the trial court that the defendant's warnings were adequate. Cochran v. Brooke, 243 Ore. 89, 409 P.2d 904 (1966). 
perhaps it is sound to treat such standards of safety as minimal only. There is a vast difference between a drug for treatment of dandruff, ${ }^{32}$ which may cause minor injury only, and one which may kill those who are allergic or sensitive thereto. ${ }^{33}$ The precautions to be taken by the maker should necessarily be greater in the latter case, and compliance with a general regulation for all prescription drugs may well be regarded as insufficient to meet ordimary care requirements.

\section{CONCLUSION}

In defining the scope of strict liability for injuries related to product use, attention is now increasingly focused upon the product being made and the maker of the product. The issues of liability for allergic reactions and for injuries resulting from misuse of drugs, however, suggest that there should be some limits to the maker's habihty. It would seem that a drug should be found to be "unreasonably dangerous" as a condition to the imposition of strict liability. ${ }^{34} \mathrm{~A}$ drug or any other product is unreasonably dangerous, I suggest, if, and only if, a reasonable man, with knowledge of the condition of the product and an appreciation of all the risks as found to exist at the time of the trial, would not now market the product at all or would do so pursuant to a different set of warnings and instructions as to use.

Assuming this basic standard, and in the light of the observations suggested by the MER/29 cases, several propositions seem clear. No distinction should be made between risks of harm that are scientifically knowable and those that are not. In other words, courts should assess habihty only by weighing the risks as found to exist at the time of trial and not the

32 In a case involving a drug called "Sebizon" for treatment of dandruff, plaintiff failed to recover because the maker complied with the FDA regulations as to warnings. In that case the plaintiff purchased the prescription drug from a druggist without a prescription. The drug bottle was labeled with a warning: "Caution: Federal law prohibits dispensing. without prescription." The plaintiff argued that maker should have warned against using without prescription rather than saying simply it should not be dispensed without such since it would be rcasonably foreseeable that product would occasionally be sold without a prescription. The court concluded that there was no negligence as a matter of law and that plaintiff's own negligence caused the injuries. Kaspirowitz v. Schering Corp., 70 N.J. Super. 397, 175 A.2d 658 (1961).

33 In Cochran v. Brooke, 243 Ore. 89, 95, 409 P.2d 904, 907 (1966), the court remarked: "It is, indeed, easy for compassion to dictate an absolute liability against the makers of a product that can cause blindness. But once the liability is imposed, it could not be judicially limited only to cases involving disastrous consequences." It would not seem too farfetched to distinguish between a drug that is calculated to cause serious injury or death from an allergic reaction and one where the reaction is practically never serious in nature.

34 See Restatement (Second) of TORTs $\& 402 \mathrm{~A}$, comments $g-k$ (1965); Keeton, Products Liability-Some Observations About Allocation of Risks, 64 Mrcr. L. Rev. 1329, 1335 (1966); Keeton, Products Liability-The Nature and Extent of Strict Liability, 1964 Ir工. L.F. 693, 702 (1964); Wade, Strict Liability of Manufacturers, 19 Sw. L.J. 5,13 (1965). 
risks as they appeared at any point in the past. The risk of harm from allergies or any other predisposition to injury from the use of a good product-one that is not unreasonably dangerous-should be allocated to the user so long as the product was accompanied by appropriate warnings and instructions. Finally, as to drugs that have been approved and not later withdrawn, the FDA's approval should preclude recovery on theories of strict liability in the absence of an unimtended condition if appropriate warnings were given. However, because withdrawal should be conclusive that the drug was unreasonably dangerous at the outset, the maker should be hable for all injuries resulting from its use. This would not, of course, preclude recovery on the theory of fraud or negligence by the maker in inducing the FDA to give its approval. 